IZA DP No. 4595

Institutional Arrangements, Employment

Performance and the Quality of Work

Werner Eichhorst

Paul Marx

Verena Tobsch

November 2009 


\title{
Institutional Arrangements, Employment Performance and the Quality of Work
}

\author{
Werner Eichhorst \\ $I Z A$
}

Paul Marx

IZA

Verena Tobsch

$E-X-A K T$

\section{Discussion Paper No. 4595 \\ November 2009}

IZA

P.O. Box 7240

53072 Bonn

Germany

Phone: +49-228-3894-0

Fax: +49-228-3894-180

E-mail: iza@iza.org

Any opinions expressed here are those of the author(s) and not those of IZA. Research published in this series may include views on policy, but the institute itself takes no institutional policy positions.

The Institute for the Study of Labor (IZA) in Bonn is a local and virtual international research center and a place of communication between science, politics and business. IZA is an independent nonprofit organization supported by Deutsche Post Foundation. The center is associated with the University of Bonn and offers a stimulating research environment through its international network, workshops and conferences, data service, project support, research visits and doctoral program. IZA engages in (i) original and internationally competitive research in all fields of labor economics, (ii) development of policy concepts, and (iii) dissemination of research results and concepts to the interested public.

IZA Discussion Papers often represent preliminary work and are circulated to encourage discussion. Citation of such a paper should account for its provisional character. A revised version may be available directly from the author. 
IZA Discussion Paper No. 4595

November 2009

\section{ABSTRACT \\ Institutional Arrangements, Employment Performance and the Quality of Work}

The observation of highly regulated, but successful economies has given rise to the hypothesis of various viable models of labor market adaptability. The paper presents a quantitative indicator that tries to avoid a simplified flexibility-rigidity dichotomy and provides a detailed picture of the varying institutional configurations by which flexibility is achieved. In order to capture different patterns of flexibility, we differentiate between five types of flexibility which can be combined (external-numerical, internal-numerical, external-functional, Internalfunctional, and wage flexibility). Following the dominant analytical perspective in comparative labor market research the indicator is limited to the institutional level (de jure variables). Besides institutional variables influencing external numerical flexibility (employment protection, unemployment benefit system and active labor market policies, taxation and wage setting) we include further institutions which can be assumed to influence adaptability (education, working-time arrangements and firm-specific vocational training).

JEL Classification: J38, J58, J28

Keywords: labor market institutions, flexibility, indicators

Corresponding author:

Werner Eichhorst

IZA

P.O. Box 7240

53072 Bonn

Germany

E-mail: eichhorst@iza.org

\footnotetext{
* The authors are grateful for comments received at the ILO Conference on "Regulating for Decent Work", Geneva 8-10 July 2009, and the IZA/Volkswagen Foundation Topic Week on the Political Economy of Labor Market Reform in Transition and Emerging Economies, Bonn, 7-10 October 2009.
} 


\section{Introduction: the theoretical framework}

Labor market flexibility is a controversial topic. It is often argued that the integration of national economies into global markets makes them more vulnerable to structural changes and therefore forces them to enhance their adaptive capacities. The openness of economies brings along a higher frequency of shocks, which requires a great deal of flexibility from the labor force in terms of occupational and geographical mobility or wage moderation. The same is true for companies facing a more volatile demand and enhanced pressure to adapt their head count. While some claim this challenge is best met with a maximum of freedom in the markets (e.g. IMF 2003), others believe in the possibility to sustain national labor market arrangements and production models. Notwithstanding the different normative perspectives with regard to the appropriate direction of reforms, it is obvious that globalization increased the pressure on policy makers to deregulate economies. This is visible in various reform agendas, not least affecting labor markets. However, these developments were anything but uniform across countries. Quite to the contrary, international comparisons reveal very different responses. Obviously, there are diverging paths of flexibility which can turn out to be functionally equivalents. The observation of less market-driven, but still economically successful countries has given rise to the hypothesis of various viable models of market adaptability. In accordance with this, the indicator presented in this paper tries to avoid a simplified flexibility-rigidity dichotomy. Starting from the assumption that all economies need some adaptive capacity but can choose between different mixtures of flexibility, the indicator is designed to give a detailed picture of the varying institutional configurations by which this flexibility is achieved.

\subsection{Labor market flexibility}

In order to capture different patterns of flexibility, we refer to a widely used typology going back to the work of Atkinson (1984) pointing at two dimensions of labor market flexibility: first, it differentiates between internal and external flexibility, i.e strategies which are applied inside a company or to the outside labor market, respectively; second, flexibility either derives from variation of workload (numerical) or from organizational adaptability (functional). A third way is to adjust wages and labor costs to the economic situation. Considering these criteria, five types of flexibility can be distinguished:

(1) External numerical flexibility means the possibility to adapt the number of employees to the economic situation by layoffs or hirings (permanent or temporary). Determinants of external numerical flexibility are the strictness of

employment protection for open-ended and fixed-term contracts and the 
quantitative availability of manpower. The latter is influenced by features of the benefit system influencing labor supply. The same is true for taxation of labor and its combined effect with the benefit system. High tax wedges and marginal effective tax rates can lead to several "traps" that provide incentives to remain inactive, unemployed or in a low-pay job.

(2) Internal numerical flexibility is achieved without variations in the number of staff. It allows for adjustment of working time via overtime or working time accounts in order to meet a company's current utilization rate.

(3) External functional flexibility requires a skilled labor force adaptable to structural changes. Skill mismatch in the labor market can be avoided by promoting occupational mobility through active labor market policies, in particular job placement and training. A prerequisite for an adaptable labor force is the provision of appropriate primary, secondary and tertiary education to create a basis for lifelong learning.

(4) Internal functional flexibility means the ability to react on changing demand with a flexible organization of the production process. This requires broad and welleducated employees able to perform different tasks. Thus, investment in firmspecific human capital via continuous (internal) qualification makes a major contribution to this type of flexibility.

(5) Wage flexibility is given when real wages can respond to changing macroeconomic conditions such as shocks. Wage rigidities result from features of a wage-setting regime such as statutory or collectively agreed minimum wages.

This typology provides a proper analytical framework as it allows for the identification of different modes of labor market flexibility instead of simply referring to the 'perfect market' as a benchmark. An underlying assumption in the design of an overall indicator is that the types of flexibility can support or substitute each other in such a way that all labor markets develop some forms of adaptability. A similar level of overall adaptability can be achieved by alternative flexibility mixes.

The European phenomenon of persistent mass unemployment following the 'golden' postwar era shifted the focus of comparative labor market analysis. Instead of shocks, institutional rigidities were increasingly regarded as explanatory factors for employment outcomes (Blanchard 2006). Since the 1990s, institutions are at the core of the debate about varying national labor market patterns. A large number of theoretical and empirical studies suggest an at least partly causal relationship between institutional arrangements and labor market performance (Nickell 1997, Nickell et al. 2005, Bassanini/Duval 2006). It is argued that adverse institutions lead to a persistent deviation from labor market equilibrium by distorting price- and wage-setting mechanisms. In this sense, four groups of labor market institutions are typically accused to create or increase unemployment: the wage-setting arrangement, unemployment benefits, taxation, and employment protection. Active labor market policies form a fifth group of institutions with 
significant influence on employment outcomes. However, they have to be considered rather supportive than adverse (Eichhorst et al. 2008).

Focusing on these 'classical' institutions risks neglecting important aspects of flexibility as they do not represent all forms of flexibility inherent in the typology above. To create an encompassing measure of labor market flexibility, the analysis has to be extended to additional institutional factors. The most important one is education (including early-childhood education, vocational training, and life-long learning). Another blind spot of most research is internal flexibility. This leads to biased results as in many countries flexible working-time models provide a compensation for rigid hiring-and-firing practices. Besides working time, organizational aspects make a major contribution to internal flexibility. Versatile workers provide an opportunity to respond to changing external conditions without drawing on resources from the external market (Seifert/Tangian 2007).

On the whole, eight sets of external and internal labor market institutions have to considered:

1. Probably the most classical explanatory factor is the wage setting arrangement due to its direct influence on wage flexibility in terms of nominal and real rigidities and wage dispersion. In terms of institutions, the extent of unionization, coverage by collective agreements or binding minimum wages and the degree of centralization and co-ordination of wage bargaining through corporatist arrangements are the most relevant features. Wage adjustment is often seen as particularly efficient in a) decentralized bargaining structures with most wages being set at the individual or enterprise level due to the direct consideration of market forces or b) in $a$ centralized and co-ordinated fashion which facilitates wage moderation. Hence, regarding wage moderation and wage flexibility both centralized and decentralized regimes can be beneficial. Wage dispersion is assumed to be more pronounced in decentralized regimes with low bargaining coverage and low or nonexistent binding minimum wages.

2. Unemployment benefits, i.e. passive labor market policies, provide income replacement in case of non-employment. In a wider sense, this not only comprises unemployment insurance, but also social assistance, different forms of disability pensions and early retirement schemes. Through the provision of income replacement, unemployment benefits can provide some human capital insurance for qualified workers in the early phase of unemployment. However, unemployment benefits may reduce job search intensity and labor supply by presenting negative work incentives and raising the reservation wage as they provide an implicit wage floor.

3. Taxes on labor, in particular income taxes and non-wage labor costs stemming from social insurance contributions, can reduce labor demand and labor supply. The extent of this effect depends on the actual tax burden of employers and/or employees taking wage adjustments into account. 
Negative effects are more probable in the case of low-wage jobs where nonwage labor costs are not borne by the worker but by the employer since the benefit system works as an effective wage floor.

4. Employment protection, i.e. provisions for dismissal protection and restrictions on temporary employment and temporary work agencies, can influence the adaptation processes by raising layoff and hiring costs. While it stabilizes jobs and sets incentives for continuous training, it can hamper adjustment to changes by reducing mobility in the labor market. Given the protection of regular employees, employment protection can lead to stronger wage pressure from labor market insiders. Employment protection can reduce the reemployment opportunities of outsiders and entrants and deepen labor market segmentation.

5. Active labor market policies can facilitate a better matching on the labor market through placement support, raise productivity through publicly sponsored training and compensate for productivity deficits by hiring subsidies. By improving the human capital of the unemployed and intensifying job search through tight monitoring, they can increase competition on the labor market, help avoid bottlenecks and facilitate wage moderation. The use of active schemes for activation helps counter potential work disincentives stemming from generous unemployment benefits. However, ineffective labor market policies can hamper employment performance due to negative tax effects.

6. Education and training affect both labor demand and supply, because skilled workers are more attractive to employers and their investment in human capital raises the opportunity costs of inactivity. As a consequence, employment as well as unemployment rates are strongly related to the educational background. Decent initial education can produce considerable long-term benefits, as it determines adaptability and employability over the life-course. This effect is facilitated by life-long learning.

7. Working-time arrangements are a functional equivalent to external numerical flexibility. Non-standard working time models, such as overtime, part-time, flexible working hours and working time accounts, allow for adjustment to workload peaks and slumps without hiring and firing. Depending on the question whether changes in working-time are compensated, such arrangements can entail significant wage flexibility.

8. Human capital investment in a firm-specific setting, i.e. the creation and maintenance of polyvalent work-related skills by formal and informal adult job-related learning increases the ability to respond to changing market requirements. Shifting workers between departments, tasks or branches without the need of extensive retraining can supplement working-time flexibility as a means of internal restructuring. 
While mainstream economic reasoning would suggest that those institutional configurations which leave quite some leeway for market forces tend to exhibit superior performance, another strand of literature emphasizes interactions between institutions and thereby paints a more complex picture of their macroeconomic effects. Institutional complementarities can explain why more regulated types of labor markets can produce favorable outcomes despite their rather 'inflexible' institutions. In this perspective, institutions - which would be considered inefficient, if regarded isolated - work as important stabilizers as they help overcome problems of collective action. This perspective is most prominently advocated by the Varieties of Capitalism approach developed by Hall and Soskice (2001). In this framework, the comparative institutional advantage of either type of capitalism is explained by a distinct equilibrium between the complementary institutions of labor market regulation, social protection, industrial relations and skill creation (Estevez-Abe et al. 2001). In liberal market economies, such as the USA or UK, market mechanisms are more pronounced and firms can operate in a highly flexible environment. In contrast, coordinated market economies such as Germany or Japan derive their comparative advantage from strong non-market coordination. Institutions supporting stable employment also encourage investment in firm-specific human capital. This feature can be considered a precondition for the high-quality production found in many coordinated market economies - hence, numerical external flexibility and wage flexibility, which are often taken as the core features of flexibility, are substituted for by internal functional and numerical flexibility.

In terms of macro-economic efficiency, empirical facts rather suggest a multi- or at least dual-peaked landscape than one single superior model outperforming the rest (Freeman 2000, Bassanini/Duval 2006). Institutionalized corporatism has been identified as a source of the favorable employment outcomes observable in some European states despite rather strong market regulation and more generous welfare state provisions (e.g. in Austria, Denmark, and the Netherlands) - if sufficient flexibility is given by 'flexicurity' policies and activation. The consensusbuilding capability of 'corporatist governance' can be especially helpful in preventing excessive wage claims and in negotiating comprehensive reform packages (Auer 2000, OECD 2006). The 'flexicurity' concept demands the reconciliation of flexibility and security elements in the labor market, so that greater mobility risks can be compensated by an appropriate security net (Tros and Wilthagen 2004). The prime example in this context is Denmark with its 'golden triangle' of low employment protection, generous unemployment benefits and high spending on active labor market policies (OECD 2004; Madsen 2006). The good employment performance of countries like Denmark or the Netherlands gave rise to the popularity of this concept combining social protection with activation and a flexible labor market. With its normative foundation it appears to be a more feasible reform approach compared to the orthodox liberalization paradigm. By now, it is the guiding principle of the European Employment Strategy (European Commission 2007). 
From this, we can assume that a sufficient degree of flexibility is needed for good employment performance - but this flexibility can be achieved in various ways, by more or less external or internal flexibility, more or less numerical, functional or wage flexibility. One would expect that external flexibility tends to be associated with a more inclusive, but also more diverse labor market whereas countries with more internal flexibility have a more exclusive, somehow more dualized labor market. Hence, while there may be similar overall employment rates and dynamics, different patterns of flexibility can be associated with diverging distributional outcomes and achievements in terms of quality of work.

\section{Indicator construction and data selection}

This section gives an overview on the data and the construction of the composite indicator. The most important source for data has been the OECD which in most cases provides the best material available for international comparisons. One should note that our indicator aims exclusively at the institutional level and neglects factual flexibility (which is rather treated as a dependent variable in a later stage of the analysis). This has implications for the selection of variables. In order not to confuse input and output, we prefer indicators which provide information on de jure flexibility (input) whereas indicators on factual flexibility (output) are mostly avoided. However, in cases where no (institutional) input data is available, e.g. for internal flexibility, we have to rely on output variables as reasonable proxies for the institutional design.

The selection of countries covered by the indicator was mainly driven by data availability. Hence, the indicator covers all OECD member states except for Turkey, Mexico, Greece, Iceland and Luxembourg (because of incomplete data). The number of countries thereby amounts to 25 . 
Table 1: Composition of sub-indicators and data sources

\begin{tabular}{|c|c|c|c|}
\hline $\begin{array}{l}\text { Sub- } \\
\text { Indicators }\end{array}$ & Institution & Variables & Source \\
\hline \multirow{4}{*}{$\begin{array}{l}\text { External- } \\
\text { numerical }\end{array}$} & $\begin{array}{l}\text { Employment } \\
\text { Protection }\end{array}$ & $\begin{array}{l}\text { Summary indicator of EPL stringency } \\
\text { (temporary and regular contracts) }\end{array}$ & OECD (2004) \\
\hline & \multirow{2}{*}{$\begin{array}{l}\text { Benefit } \\
\text { System }\end{array}$} & Net replacement rates ( $1^{\text {st }}$ and $60^{\text {th }}$ month $)$ & $\operatorname{OECD}(2007 a)$ \\
\hline & & Strictness of availability criteria & Hasselpflug (2005) \\
\hline & Taxation & Tax wedge (absolute and marginal) & $\operatorname{OECD}(2007 \mathrm{~b})$ \\
\hline \multirow{3}{*}{$\begin{array}{l}\text { External- } \\
\text { functional }\end{array}$} & ALMP & ALMP spending & OECD \\
\hline & \multirow[t]{2}{*}{ Education } & $\begin{array}{l}\text { Educational attainment } \\
\text { (at least upper secondary and tertiary) }\end{array}$ & $\operatorname{OECD}(2007 c)$ \\
\hline & & Expenditure per student (primary to tertiary) & OECD (2006) \\
\hline \multirow{3}{*}{ Wage } & \multirow{3}{*}{$\begin{array}{l}\text { Wage-setting } \\
\text { regime }\end{array}$} & Collective bargaining coverage rate & OECD (2004) \\
\hline & & Collective bargaining co-ordination & OECD (2004) \\
\hline & & Wage Dispersion (D9/D1) & OECD \\
\hline \multirow{3}{*}{$\begin{array}{l}\text { Internal- } \\
\text { numerical }\end{array}$} & \multirow{3}{*}{ Working time } & Dominant respond to workload peaks & ESWT \\
\hline & & Rationale for using flexible working hours & ESWT \\
\hline & & Working-time accounts & ESWT \\
\hline \multirow{4}{*}{$\begin{array}{l}\text { Internal- } \\
\text { functional }\end{array}$} & \multirow{2}{*}{$\begin{array}{l}\text { Internal } \\
\text { qualification }\end{array}$} & Incidence of training provided by employer & EWCS \\
\hline & & Volume of non-formal job-related training & OECD (2008) \\
\hline & \multirow{2}{*}{$\begin{array}{l}\text { Work } \\
\text { organization }\end{array}$} & Incidence of task rotation & EWCS \\
\hline & & Necessity of learning new things & EWCS \\
\hline
\end{tabular}

Note: OECD references without a year indicate the online portal stats.oecd.org as a data source. ESWT $=$ Establishment Survey on Working Time and Work-Life Balance 2004/05 (Eurofound 2006). EWCS $=4^{\text {th }}$ European Working Conditions Survey (Eurofound 2007).

Based on our theoretical framework, the composition of sub-indicators (functional internal, numerical internal, functional external, numerical external and wage flexibility) followed a three step procedure. The first step included the imputation of missing values, the standardization of variables and data reduction by means of factor analysis ${ }^{2}$. Finally, some resulting variables were reversed so that high values indicate (theoretically) a higher degree of flexibility than lower values. In the second step, these input variables were weighted and summarized either manually (based on theoretical considerations) or by means of factor analysis in order to retrieve single variables indicating the flexibility of each institution considered in this framework. The resulting variables were transformed such that the corresponding sub-indicators have the same scale (mean of 12) and in order to avoid negative values for better interpretation. In some cases truncation of values was applied. The construction of sub-indicators followed in the third step a simple composition of the transformed institutional variables by summarizing the corresponding institutional variables (with equal weighting). ${ }^{3}$

\footnotetext{
${ }^{2}$ All factor analyses used principal component analysis, Promax rotation in order to allow for correlation of factors and Kaiser-normalization. Imputation relied on country cluster averages.

${ }^{3}$ See Annex for detailed description.
} 


\subsection{External numerical flexibility}

Due to the interplay of different taxes, tax reliefs and benefits, measuring the tax burden on labor is a complex task. The OECD models a representative average worker for whom the net income is computed (considering different family and income situations). On the basis of this, the tax wedge can be calculated. It is defined as the difference between the labor costs to the employer and the net takehome pay of the employee. To compute the tax wedge, benefits are deducted from the sum of personal income tax, social security contributions and payroll tax. The result is expressed as a percentage of labor costs. The average tax wedge serves as a proxy for the overall tax burden of labor. Another question is which incentives are generated by the tax system to expand labor supply. This feature is expressed by marginal tax rates, i.e. the share of a pay raise that is taxed away. Both, average and marginal tax wedges for different constellations, are incorporated into the indicator.

By means of factor analysis we could extract two factors: one includes the tax wedge variables for all family types and the other includes marginal tax wedge variables for families with low income only. Both factors were reversed because high tax wedges and high marginal tax wedges correspond to less flexibility. Finally both factors were combined by factor analysis at the second stage resulting in one institutional variable indicating the flexibility of taxation. Both variables were given equal weights by means of factor analysis. The resulting variable was transformed to mean of 4 and standard deviation of 2 .

Broadly speaking, the generosity of the benefit system is determined by three dimensions: the extent of income maintenance, its duration and the conditions for benefit receipt. Income maintenance is captured by replacement rates, i.e. the proportion of in-work income that is maintained during unemployment. As the tax treatment of benefits differs across countries, gross figures are biased and therefore inconclusive for cross-sectional comparison. Thus, net replacement rates (NRR) are employed. The duration (or the degressive character) of benefits can be approximated by differentiating between initial and long-term unemployment. The OECD provides NRRs for the first and the 60th month of unemployment and for different family types which are included in the indicator. These variables are highly correlated and were therefore reduced in the first stage by means of factor analysis resulting in two factors that separate initial net replacement rates from net replacement rates after 60 th month regardless of family type.

Measuring the third dimension of generosity, the strictness of availability criteria (SAC), is a more challenging task. Countries usually establish complex regulations to offset the negative motivational effects of generous benefits. The Danish Ministry of Finance (1998) and Hasselpflug (2005) developed an index for the strictness of such rules, e.g. the demands on job search activity, valid reasons for job offer refusal, expected geographical and occupational mobility, availability for 
ALMP, and sanctions for the rejection of reasonable job offers. After imputation of missing values by cluster means ${ }^{4}$, this variable was standardized. ${ }^{5}$ High values for SAC indicate a more flexible labor market, but high net replacement rates would lead to less flexibility. Therefore the two factors of net replacement rates were inverted.

The final institutional indicator for the benefit system was computed in the second stage by taking the average of all three variables but giving initial net replacement rate double weight: $1 / 2$ for initial net replacement rate, $1 / 4$ for net replacement rate after 60 th month, and $1 / 4$ for SAC. The resulting variable was transformed to mean 4 and standard deviation of 2 .

For the measurement of employment protection the OECD summary indicator of the stringency of employment protection legislation (EPL) is virtually the only appropriate instrument. It consists of three subjectively weighted sub-indicators (dismissal protection for regular workers, regulation of temporary employment, restrictions for collective dismissals) and altogether 18 items. In our indicator, EPL for regular and temporary contracts is included. Both variables were standardized to mean 0 and standard deviation 1 in the first stage as well as inverted because high protection would result in lower labor market flexibility. The final variable indicating labor market flexibility with respect to EPL was computed by taking the average of both input variables, but giving protection for regular work contracts double weight: $1 / 3$ for temporary and $2 / 3$ for regular. ${ }^{6}$ The resulting variable was transformed to mean of 4 and standard deviation of 2 .

At the third stage the sub-indicator for external numerical flexibility was computed by summarizing the institutional variables: taxation, benefit system and employment protection legislation. Since all of these variables were transformed to mean 4, a value of 12 for the sub-indicator indicates the average of each institutional variables or the average of all three by compensation of low and high values. However, values below (or above) 12 indicate lower (respectively higher) external numerical flexibility than average of all countries considered.

\subsection{External functional flexibility}

To measure the contribution of the education system to labor market flexibility three variables were used: the expenditure on education per student from primary to tertiary education, educational attainment in upper secondary education and

\footnotetext{
${ }^{4}$ Clustering of all countries was based on all input variables used for external and wage flexibility. For Poland a value of 3,7 and for Korea a value of 2,8 was imputed.

${ }^{5}$ With mean 0 and standard deviation of 1.

${ }^{6}$ Because of manual weighting the standard deviation of the resulting variable changes whereas the mean remains zero. It was standardized to standard deviation of one in order to have the same scale like factors retrieved from factor analysis.
} 
educational attainment in tertiary education. The first variable was standardized, the latter two variables were derived from factor analysis by using two variables each: the educational attainment in percent of those aged 25 to 34 and of those aged 25 to 64 . The loadings of factors clearly showed two factors separating upper secondary and tertiary educational attainment. The weights or factor loadings were almost equal.

We suppose that the educational system is more flexible regarding labor market flexibility if educational attainment of upper secondary or tertiary education is high (high quantity of qualified employees available) and expenditures per student is high (indicating higher quality of education). Factor analysis supported this relationship since all three input variables resulted in one factor with almost equal weights for tertiary educational attainment and expenditures and a slightly lower weight for upper secondary educational attainment. The resulting factor was transformed to mean equal 6 and standard deviation of 3 .

The sub-indicator for active labor market policies (ALMP) should reflect the extend to which countries rely on instruments under this heading to intervene in the labor market. For the measurement, expenditure figures and participant stocks are available. However, both data are misleading as high unemployment increases spending and participation. To obtain a proxy for different policy choices unbiased by unemployment level and GDP size, the ratio of ALMP spending per unemployed to GDP per labor force is computed.

ALMP Spending / Unemployment

GDP / Labor Force

As countries differ significantly in how they use ALMPs, data is broken down into three broad categories of spending: training schemes, activation instruments mainly addressing the first labor market (start-up or employment incentives), and instruments creating a sheltered labor market (e.g. direct job creation). Spending on public employment services is available; however, it is not included in the indicator, since it rather indicates administrative complexity than the quality of labor market institutions. After standardization, the three variables were used for factor analysis in order to derive one institutional variable indicating the flexibility of active labor market policies.

We assume the labor market to be more flexible the higher expenditures on ALMP measures are since they support the adaptability of the labor force. Factor analysis resulted in one factor with almost equal weights for expenditures on training and activation in the first labor market and a slightly lower weight for expenditures on the secondary market. The resulting institutional variable was transformed to mean 6 and standard deviation 3.

At the third stage the sub-indicator for external functional flexibility was computed by summarizing the institutional variables education and ALMP. Since both of 
these variables were transformed to mean 6, a value of 12 for the sub-indicator indicates the average of each institutional variables or the average of both by compensation of low and high values. However, values below (or above) 12 indicate lower (respectively higher) external functional flexibility than average of all countries considered.

\subsection{Wage flexibility}

Wage flexibility is measured by two variables: wage setting and wage dispersion. Collective bargaining coverage and co-ordination provide information about the wage-setting regime. The former expresses the share of workers covered by collective agreements. High coverage is supposed to decrease wage flexibility because it is associated with downward wage rigidity imposed by collective agreements. It typically leads to wage compression to the detriment of lowproductivity segments of the labor market. However, in line with the literature, we assume that the negative effect of bargaining coverage can be partly offset by a strong corporatist organization of the bargaining process ${ }^{7}$. To include this dimension, we employ the OECD indicator of collective bargaining co-ordination. It distinguishes five levels of co-ordination and subjectively assigns scores to them (OECD 1997, 2004). The scale ranges from 1 (fragmented bargaining on company level) to 5 (strong co-ordination through peak confederations or government involvement). In accordance with the 'hump hypothesis', we assume wage flexibility to be positively related to the absolute deviation from the mean (because very liberal and very corporatist models should theoretically outperform economies with an intermediate level of coordination). According to our theoretical framework, the negative consequences of high coverage are less severe in cases where coordination supports wage moderation. To account for this interaction, we divided the coverage rate by the absolute deviation from the mean of the coordination index. Consequentially, strong coordination reduces the adverse effects of high coverage ${ }^{8}$.

Together, the two combined indicators provide information on how many employees are covered by collective agreements and under which conditions their wage is determined. But as considerable shares of the workforce can be excluded

\footnotetext{
${ }^{7}$ According to the hump-shape hypothesis - suggested by Calmfors and Driffill (1988) - not only countries with decentralized bargaining, but also highly coordinated ones perform better in terms of unemployment than countries with intermediate coordination. In highly coordinated systems wage policies tend to be more moderate, because macroeconomic consequences of excessive claims are taken into account. While it is contested whether this leads to a non-linear, hump-shaped relationship, it can be shown that coordination decreases unemployment (e.g. OECD 2006).

${ }^{8}$ The somewhat arbitrary calculation is justified by the fact that it allows for the inclusion of a more complex picture of wage flexibility. An alternative would have been to follow the neoclassical conception in which only competitive pressure assures wage moderation and all institutional restrictions to free bargaining are considered adverse.
} 
from such agreements, a comprehensive conception of the labor market requires supplementary information on the wage rigidities in non-covered jobs. In every labor market a wage floor exists. It can be established either by a binding minimum wage or by the reservation wage. The latter is constituted by the level of minimum income provided by social assistance. In more than two third of the cases minimum wages are set statutorily and accordingly the wage floor can be calculated as the relation of minimum to median wage. In Scandinavia, Austria, Germany, Italy and Switzerland, however, the flexibility of wages outside collective agreements is only implicitly restricted by the benefit system. Unfortunately, up to today there is no conclusive measure which would allow for a comparison of the two types of wage floors. For the purpose of comparability, the indicator has to draw on wage dispersion to approximate the downward variability of wages. Considering data availability, we employ the commonly used ratio of the top to the bottom decile of the wage distribution. For Austria, Belgium and the Slovak Republic this information had to be imputed by cluster averages. ${ }^{9}$

Both measures of wage flexibility - bargaining institutions and wage dispersion were standardized and the variable for bargaining was reversed. The institutional variable indicating the flexibility of wage setting was computed by summation of both input variables giving double weight to collective bargaining systems $(2 / 3)$ compared to dispersion $(1 / 3) .{ }^{10}$ The resulting variable was transformed to mean 24 and standard deviation of 12 .

\subsection{Internal (functional and numerical) flexibility}

In the past, research on labor market flexibility was focused on external flexibility. Thus, there are no established indicators for internal flexibility. It is also difficult to identify institutions (in the form of legal rules) that influence this kind of flexibility. Rather, it is to be seen as one aspect of a production model that is characterized by historically grown complementarities which cannot be changed directly through state intervention. Therefore, the indicator draws on surveys that investigate the working conditions in companies. These are the European Working Conditions Survey (EWCS) and the Establishment Survey on Working Time (ESWT). Unfortunately, both surveys do only cover some European countries from the original sample so that the sample size had to be reduced to 16 countries for the final stage of indicator construction. To cover internal numerical flexibility, i.e. working-time arrangements, three variables from the ESWT were included ${ }^{11}$. Internal

\footnotetext{
${ }^{9}$ For Austria and Belgium a value of 2,6 and for the Slovak Republic a value of 3,8 was imputed.

${ }^{10}$ Because of manual weighting the standard deviation of the resulting variable changes whereas the mean remains zero. It was standardized to standard deviation of one in order to have the same scale like factors retrieved from factor analysis.

${ }^{11}$ These three variables are: 1) The percentage of companies that answered with "asking regular staff to work more hours" on the question which arrangement they mostly use for coping with
} 
functional flexibility comprises two elements. First, the acquisition of firm-specific human capital plays a crucial role. Assuming that employers pay predominantly for further education that can be applied inside their company, life-long learning provided by the employer is included as an indicator for such skills. Besides the incidence of training, also its intensity is included in the indicator. The latter is expressed as expected numbers of hours in non-formal job-related continuing education and training over a typical working life (OECD 2007c). The second aspect of internal functional flexibility is work organization. Here, two variables from the EWCS ${ }^{12}$ were used that help to distinguish production models based upon simple ('Taylorist') work organization and models in which more complex modes of organization prevail.

Our indicators of internal flexibility add up to seven variables. Factor analysis resulted in two factors with the following variables being related to internal functional flexibility (almost equal weights): percentage of employees who undergo training paid or provided by employer, percentage of employees learning new things during job, percentage of employees having rotating tasks. The strategy of 'asking staff to work more hours during work peaks', the use of flexible working hours to adapt to work load, and working-time accounts are related to internal numerical flexibility.

While factor analysis clearly separates the incidence of training from variables indicating working-time arrangements, the intensity of life-long learning is loading on both factors - even if the weight is rather low. That means, in countries where the intensity of job related training is high (low) the number of employees undergoing job-related training, the percentage of employees learning new things or having rotating tasks as well as the percentage of firms using flexible work time arrangement is high (low). Both resulting factors were transformed to mean 12 and standard deviation of 6 .

\subsection{Building a composite indicator of labor market flexibility}

Each sub-indicator can be summarized according to the framework to generate indicators of internal, external and wage flexibility which then can be summed up to achieve an overall index of labor market flexibility. For a country scoring average in all institutional variables the resulting overall index of flexibility (by summarizing all sub-indicators) sums up to 60 . It has to be kept in mind however that the standard deviations will be different between the sub-indicators since some are calculated as the sum of institutional variables and some are retrieved from factor

workload peaks; 2) Percentage of companies saying the rationale for the introduction of flexible working hours was to make working time more adaptable to variations in workloads; 3 ) Percentage of companies using working-time accounts.

${ }^{12}$ Percentage of workers whose main paid job involves learning new things or rotating tasks. 
analysis. A country one standard deviation below the mean in each institutional variable would score 6 for functional external flexibility, 6 for numerical external flexibility (resulting in 12 for external flexibility), 6 for functional internal and 6 for numerical internal (resulting in 12 for internal flexibility), and 6 for wage flexibility. ${ }^{13}$

\footnotetext{
${ }^{13}$ See Annex for further explanation and real standard deviations of sub-indicators.
} 
Chart 1: Structure of the Composite Indicator with Scores for Sub-indicators (Circled Numbers)

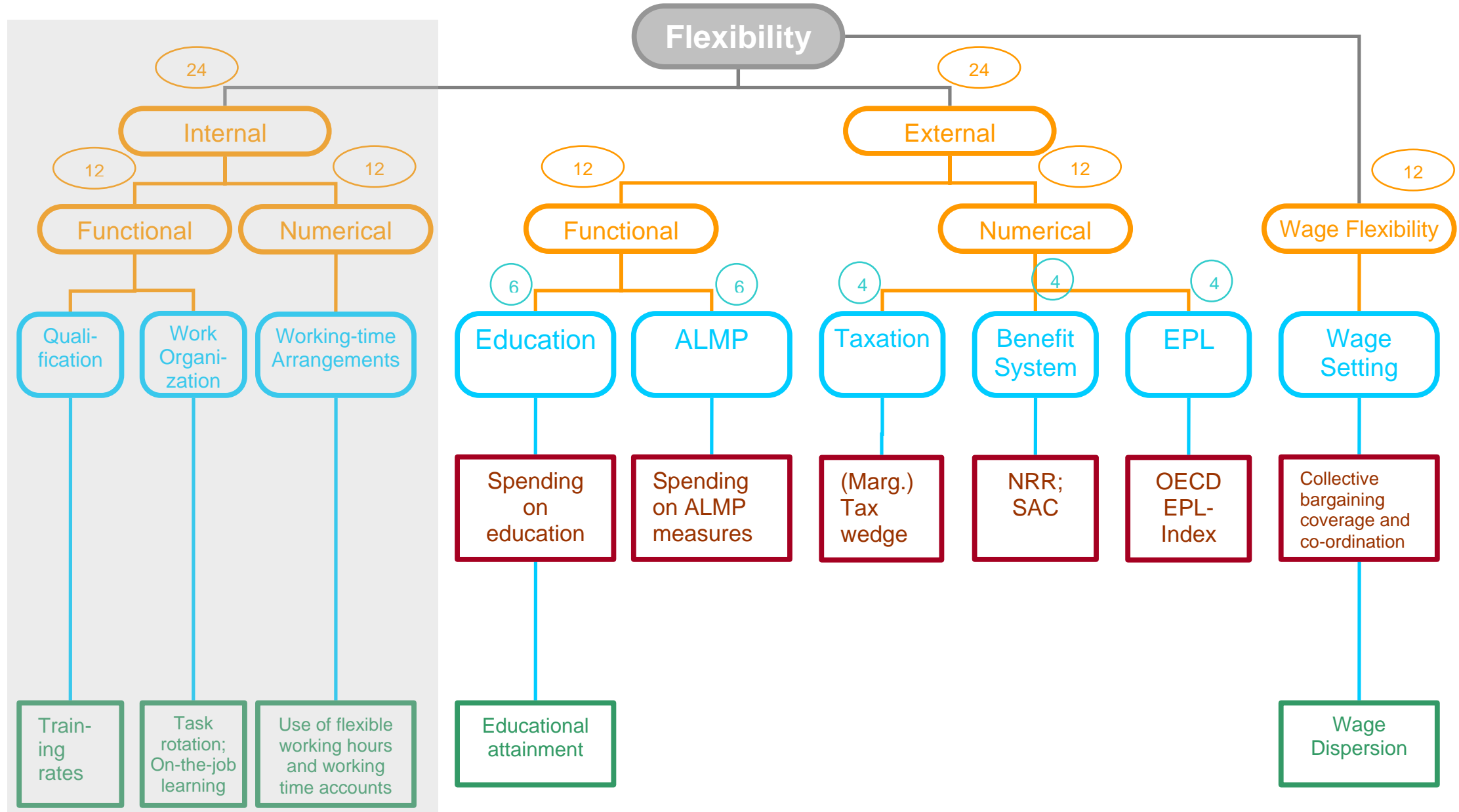

$\mathrm{NRR}=$ Net replacement rate $; \mathrm{EPL}=$ Employment Protection Legislation $\mathrm{SAC}=$ Strictness of Availability Criteria; $\mathrm{ALMP}=$ Active Labor Market Policies 


\section{Results}

Chart 2 presents the countries ranked by external and wage flexibility with the former being broken down into numerical and functional flexibility. High figures indicate high flexibility. As one would expect, the Anglo-Saxon countries are well represented among the top ten (USA, Canada, New Zealand, Ireland, and UK). This is mainly due to their high wage and external numerical flexibility while external functional flexibility is rather average. Labor market flexibility is also high in Japan and Korea and in some of the new OECD member states, namely in Hungary, and to a smaller extent in Poland and the Czech Republic. While the CEE transition economies significantly liberalized their labor market institutions (with the exception of Slovakia), the indicator reveals very weak performance in terms of functional flexibility. Although Switzerland and Denmark perform somewhat better, most Continental European and Scandinavian countries are located in the bottom half of the ranking. The indicator seems to confirm the criticism, according to which these countries have more protective or 'rigid' institutions in the external labor market and inflexible wage setting. However, concerning functional flexibility, especially the Scandinavians outperform the rest of the sample.

\section{Chart 2: External and wage flexibility, 2003}

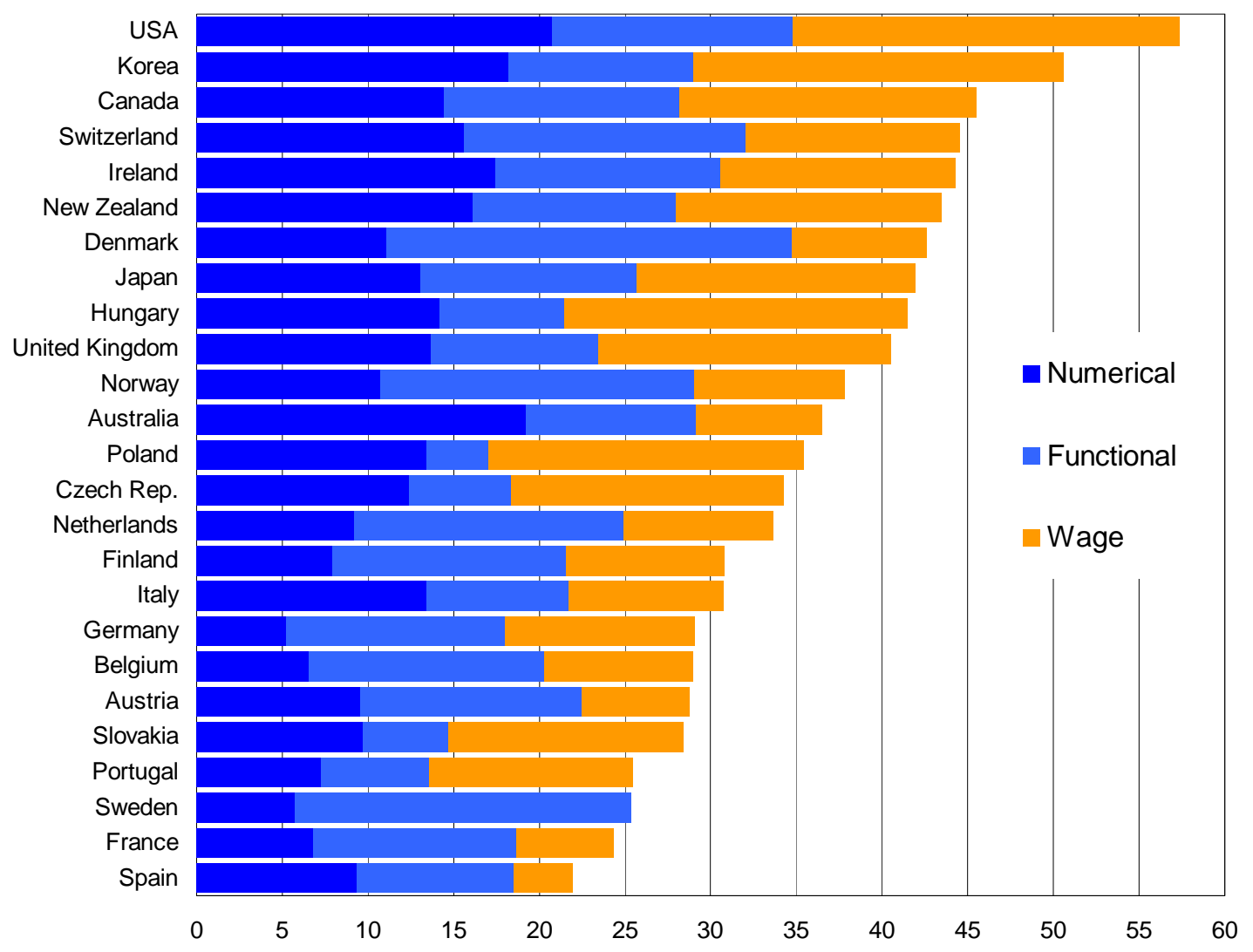


The overall picture changes when internal flexibility is taken into consideration (chart 3). As this type of flexibility is more pronounced in Continental European and Scandinavian countries than in Anglo-Saxon and CEE countries, they improve their position in the ranking. This is especially true for Denmark, Sweden and Finland where internal functional flexibility is strong. Germany, France and Finland heavily rely on flexible working-time arrangements. The comprehensive analysis of labor market flexibility reveals severe structural weaknesses in the Mediterranean countries. Since they combine weak internal flexibility with rather rigid institutions in the external labor market and in wage setting, Italy, Portugal and Spain are at the bottom of the ranking.

\section{Chart 3: Internal, external and wage flexibility, 2003}

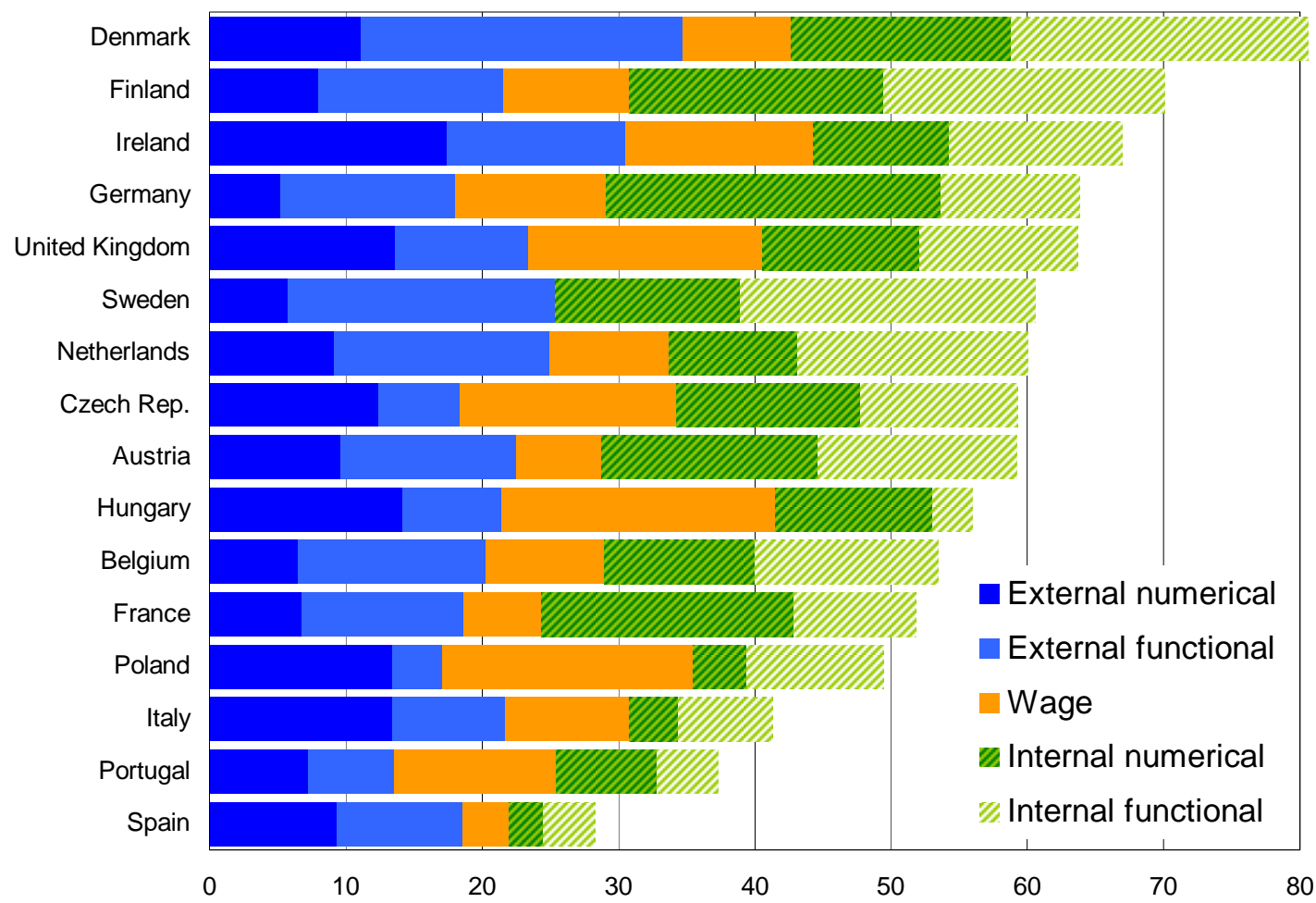

\subsection{Cluster Analysis}

To obtain information beyond a ranking of countries, clusters with similar patterns of flexibility can be formed. Starting with a cluster analysis based upon external and wage flexibility only, the groupings more or less resemble the familiar picture of established typologies (chart 4). The first cluster can be labeled 'educationbased' and comprises nine Scandinavian and Continental-European countries. It is characterized by low external numerical and wage flexibility, while external 
functional flexibility is high. The second cluster combines high external numerical and wage flexibility with intermediate external functional flexibility. Due to the strong reliance on undistorted market mechanisms, this cluster can be called 'market-oriented I'. It is formed by the Asian and the Anglo-Saxon countries. The third group consists of the four countries from Central and Eastern Europe, which have high external functional and wage flexibility, but very low external functional flexibility. Compared to first market-based cluster, education and training are less pronounced ('market-oriented II'). Finally, the Southern European cases find themselves in a cluster, which is characterized by rather low flexibility in all dimensions ('low flexibility cluster'). ${ }^{14}$

Chart 4: Cluster Tree external and wage flexibility, 2003 (hierarchical cluster analysis, dendrogram using ward method)

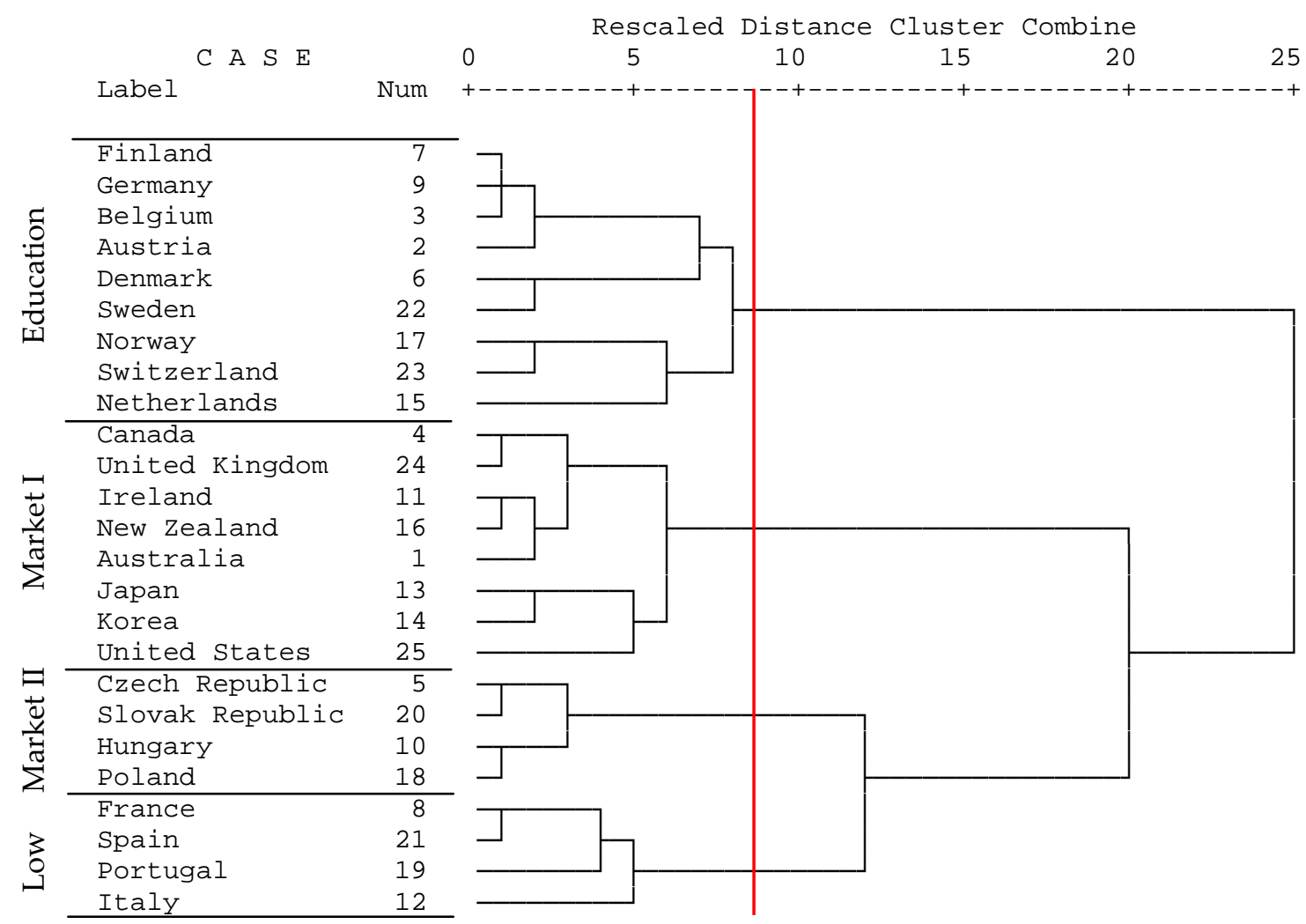

A second cluster analysis on the basis of the composite indicator can be conducted for the smaller sample of countries whose internal flexibility could be calculated (chart 5). Again, in most cases the results are consistent with expectations. As for external flexibility, the Continental and Scandinavian countries are quite similar, although Denmark and Sweden have to be treated as a separate cluster. Both exhibit strong internal flexibility, while internal functional flexibility is prevailing.

${ }^{14}$ Restricted flexibility with formal institutions can, of course, be compensated by informal work and de facto flexibility resulting from non-enforcement (Seifert/Tangian 2007). 
Overall, functional elements (internally and externally) are very important in Denmark and Sweden so that their cluster is termed 'functional model'. The remaining Scandinavian countries together with the Continental ones form the second cluster. They are characterized by an extensive use of working-time arrangements (especially Finland, France and Germany), but only by intermediate functional flexibility. In the third cluster, internal flexibility is clearly underdeveloped. It is formed by three Southern European countries: Italy, Spain and Portugal. Bearing in mind their weak external flexibility, this country group is categorized as a 'low flexibility model'. The fourth cluster consists of cases that reveal very high external and wage flexibility and is therefore labeled 'market model'. The heterogeneous group comprises two Anglo-Saxon (UK, Ireland) and three CEE countries (Czech Republic, Hungary, Poland). Contrary to what one might expect, most of these countries do not completely go without internal flexibility, but show an average level for both sub-indicators (very low values are only observed for internal numerical flexibility in Poland and internal functional flexibility in Hungary).

Chart 5: Cluster Tree overall flexibility, 2003 (hierarchical cluster analysis, dendrogram using ward method)

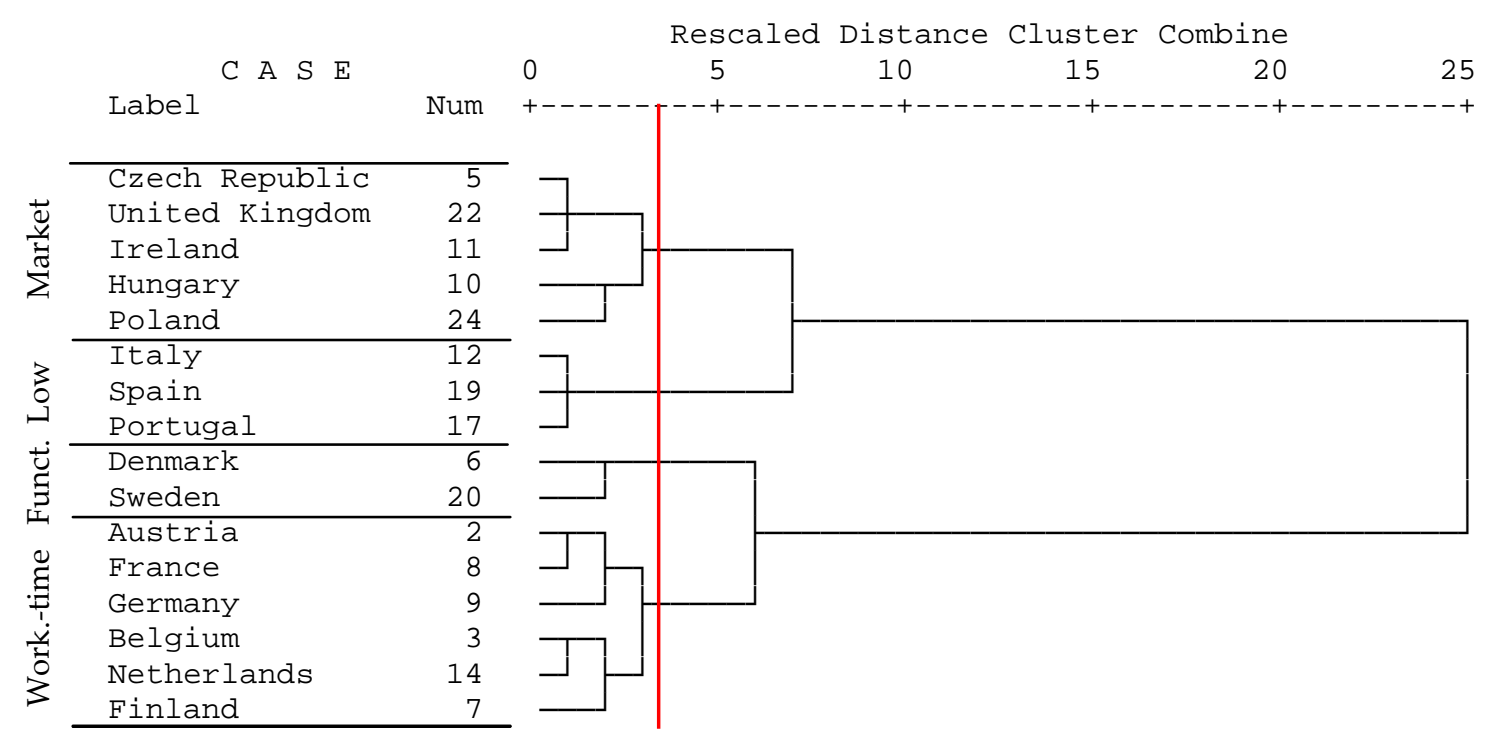




\section{Outcomes: Employment Performance, Inequality and the Quality of Work}

With respect to employment performance, inequality and quality of work, the country clusters show remarkable differences. Taking into account external and wage flexibility (version 1), the market-oriented countries show the second highest employment rates and relatively small employment gaps by age, gender or skills levels. Hence, their flexible labor markets tend to be quite inclusive. The backside of this is job instability - indicated by short average tenure - and inequality, which is the highest among the four clusters. Rather unexpectedly, the job quality index developed by Leschke et al. (2008) is equal for the (European) market-oriented countries (I) and the education-based countries. The latter exhibit slightly higher employment rates as well as relatively small employment gaps and the lowest inequality and poverty figures. The CEE market-oriented countries (II) show much lower job quality, employment rates, very severe employment gaps but limited poverty. The low flexibility cluster has a medium level of job quality, marked employment gaps - except for skills - and rather high poverty and inequality associated with long average tenure. Hence, low flexibility labor markets tend to result in somewhat dualized structures.

Table 2: Flexibility clusters and socio-economic performance (version 1: only external, version 2: with internal)

\begin{tabular}{|c|c|c|c|c|c|c|c|c|}
\hline \multicolumn{9}{|c|}{ Version 1: External and Wage Flexibility } \\
\hline Cluster & JQI & $\begin{array}{l}\text { Empl. } \\
\text { Rate }\end{array}$ & $\begin{array}{l}\text { Empl. } \\
\text { Growth }\end{array}$ & $\begin{array}{l}\text { Avg. Empl. } \\
\text { Gap }\end{array}$ & $\begin{array}{l}\text { Skill } \\
\text { Gap }\end{array}$ & $\begin{array}{c}\text { Poverty } \\
\text { Rate }\end{array}$ & Gini & $\begin{array}{l}\text { Avg. } \\
\text { Tenure }\end{array}$ \\
\hline market I & $0,67^{*}$ & 70,4 & 1,8 & 22,9 & 21,7 & 20,8 & 0,33 & $8,7^{* *}$ \\
\hline education & $0,67^{*}$ & 71,4 & 0,8 & 24,1 & 25,3 & 14,1 & 0,27 & 10,5 \\
\hline market II & 0,37 & 59 & 1,3 & 35,3 & 43,5 & 14,6 & 0,31 & 10,2 \\
\hline low flex & 0,46 & 63,3 & 1,2 & 32,6 & 12,3 & 18,9 & 0,33 & 11,3 \\
\hline \multicolumn{9}{|c|}{ Version 2: Internal, External and Wage Flexibility } \\
\hline Cluster & JQI & $\begin{array}{l}\text { Empl. } \\
\text { Rate }\end{array}$ & $\begin{array}{l}\text { Empl. } \\
\text { Growth }\end{array}$ & $\begin{array}{c}\text { Avg. Empl. } \\
\text { Gap }\end{array}$ & $\begin{array}{l}\text { Skill } \\
\text { Gap }\end{array}$ & $\begin{array}{c}\text { Poverty } \\
\text { Rate }\end{array}$ & Gini & $\begin{array}{l}\text { Avg. } \\
\text { Tenure }\end{array}$ \\
\hline market & 0,49 & 63,3 & 1,5 & 30 & 34,4 & 16,7 & 0,32 & 9,6 \\
\hline working time & 0,63 & 67,3 & 0,7 & 29,5 & 24,1 & 11,9 & 0,28 & 11,3 \\
\hline functional & 0,75 & 75,6 & 0,8 & 19,2 & 23,1 & 15 & 0,24 & 9,9 \\
\hline low flex & 0,42 & 63,2 & 1,7 & 31,9 & 9,4 & 20,5 & 0,35 & 11,1 \\
\hline
\end{tabular}

* No values for non-EU countries. Average bases on EU members only.

* No values for non-European countries. Average bases on values for Ireland and UK only.

Notes: JQI = Job Quality Index (see Leschke et al. 2008), employment rate: average 2003-2008, employment growth: average 2003-2007, average employment gap: average of the employment gaps between prime age workers and young/elder workers and between males and females, skill gap: difference in non-employment rates between medium and less educated people, poverty rate: people with disposable income after taxes and transfers below $60 \%$ of median income; Gini coefficient: based on disposable income after taxes and transfers.

Using the clustering generated from internal external and wage flexibility (version 2 ), by far the highest job quality and employment as well as the smallest 
employment gaps are achieved by the "functional" cluster. With respect to job quality and employment they are followed by the "working time flexibility" countries although their labor markets are more exclusive, i.e. with long job tenure on the one hand and pronounced employment gaps on the other - but poverty is the lowest there. The market-oriented European countries and the low flexibility countries resemble each other with lower average job quality, low employment, strong employment gaps and more poverty and income inequality. Quite unexpectedly, the skill non-employment gap is quite strong in the market-oriented cluster whereas it is small in the low flex countries.

An interesting question is if the indicator can explain the variation of output variables. In annex 2 (chart A1) external flexibility is plotted against the average employment rate between 2003 and 2008. Both variables are correlated with highflex countries performing better For example, almost all cases of the market 1 cluster are located in the upper right corner of the distribution, while the low-flex countries find themselves in the lower left corner. Thus, the results support the prevailing perspective in comparative labor market analysis according to which external institutions determine performance. Moreover, there seems to be a relationship between external flexibility and employment gaps. Theoretically, one would expect more flexible countries to be also more inclusive while in regulated systems weaker groups tend to be excluded from participation in the labor market. The results in chart A2 confirm this, since average employment gaps (including gaps between younger/elder workers and prime age workers as well between men and women) are higher in countries with less flexible external institutions.

The correlation between flexibility and employment rate is weaker if overall flexibility is analyzed (chart A3), although the changed sample size has to be taken into consideration. A possible interpretation could be that external institutions are more important for the explanation of labor market performance. But obviously countries that are able to balance out deficits by internal measures still have a significant advantage compared to cases with overall low flexibility. 


\section{Conclusions}

The overall indicator of labor market flexibility developed in this paper is based on the combination of different dimensions of flexibility represented by available institutional indicators. It shows the different patterns of flexibility across countries as well as a certain degree of similarity within four clusters of countries. Not only patterns of flexibility vary, the overall level of labor market flexibility varies across countries as does the performance of the countries with respect to core labor market and socio-economic outcomes - employment levels and dynamics, the inclusive or exclusive character of national labor markets and distributive variables. This paper only provides a first attempt at mapping labor market flexibility in a differentiated way - but existing institutional indicators can provide some approximation to complex institutional arrangements and point at different patterns of flexibility. Of course, available indicators can mirror reality only to a limited extent - this is why further and better data would help draw are more detailed picture of national labor markets. In particular, information on the actual role and relevance of formal institutions is a bottleneck as well as more detailed data on internal flexibility. 


\section{References}

Atkinson, J., 1984: Flexibility, Uncertainty and Manpower Management, IMS Report No.89, Institute of Manpower Studies, Brighton.

Auer, P., 2000: Employment revival in Europe. Labour market success in Austria, Denmark, Ireland and the Netherlands. Geneva.

Baker, D./Glyn, A./Howell, D./Schmitt, J., 2004: Unemployment and Labor Market Institutions: The Failure of the Empirical Case for Deregulation. CEPA Working Paper 2004.

Bassanini, A. P./Duval, R., 2006: Employment patterns in OECD countries: Reassessing the role of policies and institutions. OECD Economics Department Working Paper 486.

Blanchard, O., 2006: European Unemployment: The Evolution of Facts and Ideas. Economic Policy, 21(45), 5-59.

Calmfors, L./Driffill, J., 1988: Bargaining Structure, Corporatism and Macroeconomic Performance, Economic Policy, 3(6), 14-61.

Danish Ministry of Finance, 1998: Availability criteria in selected OECD-countries. Danish Ministry of Finance Working Paper 6.

Eichhorst, W./ Feil, M./Braun, C., 2008: What Have We Learned? Assessing Labor Market Institutions and Indicators. IZA Discussion Paper No. 3470.

Estevez-Abe, M./Iversen, T./Soskice, D., 2001: Social Protection and the Formation of Skills: A Reinterpretation of the Welfare State. In: Hall, P. A./Soskice, D. (Eds.), 2001: Varieties of Capitalism: The Institutional Foundations of Comparative Advantage. Oxford, 145-183.

Eurofound, 2006: Establishment Survey on Working Time and Work-Life Balance (ESWT 2004/2005). Tables by country, Munich.

Eurofound, 2007: Fourth European Working Conditions Survey, Dublin.

European Commission, 2007: Towards Common Principles of Flexicurity: More and Better Jobs through Flexibility and Security. Brussels.

Freeman, R. B., 2005: Labour Market Institutions without Blinders: The Debate over Flexibility and Labour Market Performance. NBER Working Paper No. 11286.

Hall, P. A./Soskice, D., 2001: An Introduction to Varieties of Capitalism. In: Hall, P. A./Soskice, D. (Eds.), 2001: Varieties of Capitalism: The Institutional Foundations of Comparative Advantage. Oxford, 1-68.

Hasselpflug, S., 2005: Availability criteria in 25 countries. Ministry of Finance Denmark Working Paper 12/2005. Copenhagen. 
IMF, 2003: Unemployment and Labor Market Institutions: Why Reforms Pay Off, World Economic Outlook, ch. 4, 129-150.

Leschke, J./Watt, A./Finn., M, 2008: Putting a number on job quality? Constructing a European Job Quality Indexm ETUI Working Paper 2008.03

Madsen, P. K., 2006: Flexicurity - A new Perspective on Labour Markets and Welfare States in Europe. CARMA Research Paper 2006:03.

Nickell, S., 1997: Unemployment and Labour Market Rigidities: Europe versus North America. Journal of Economic Perspectives 11( 3), 55-74.

Nickell, S./Nunziata, L./Ochel, W., 2005: "Unemployment in the OECD since the 1960s. What do We Know?" The Economic Journal, 115 (500), 2005, 01-27.

OECD, 1997: OECD Employment Outlook 1997. Paris.

OECD, 2004: OECD Employment Outlook 2004. Paris.

OECD, 2006: OECD Employment Outlook 2006. Paris.

OECD, 2006: Education at a Glance 2006. OECD Indicators. Paris.

OECD, 2007a: Benefits and Wages 2007. OECD Indicators. Paris.

OECD, 2007b: Taxing Wages 2007. OECD Indicators. Paris.

OECD, 2007c: Education at a Glance 2007. OECD Indicators. Paris.

OECD, 2008: Education at a Glance 2008. OECD Indicators. Paris.

Seifert, H./Tangian, A., 2007: Flexicurity: Reconciling Social Security with Flexibility - Empirical Findings for Europe. WSI-Diskussionspapier Nr. 154.

Tangian, A., 2007: Flexibility - Flexicurity - Flexinsurance: Response to the European Commission's Green Paper "Modernising Labour Law to Meet the Challenges of the 21st Century". WSI-Diskussionspapier Nr. 149.

Wilthagen, T./Tros, F., 2004: The concept of 'flexicurity': a new approach to regulating employment and labour markets. Transfer 2/04, 166-186. 


\section{ANNEX 1: Details of construction sub-indicators and institutional variables}

Institutional variables were transformed such that the resulting sub-indicators have the same scale (same mean and at least theoretically same standard deviation). Also negative values (factors derived from factor analyses or standardized variables in general) can be avoided for better interpretation by shifting the mean and standard deviation. Since all sub-indicators are computed as the sum of corresponding institutional variables the following procedure was used:

1) if a sub-indicator consists of three variables, these are transformed to mean 4 and standard deviation of 2 ,

2) if a sub-indicator consists of two variables, these are transformed to mean 6 and standard deviation of 3 ,

3 ) if a sub-indicator consists of one variable, this one is transformed to mean 12 and standard deviation of 6.

Although this procedure already controls for negative values, there are still some exceptions. Table A1 and table A2 show the final distribution of institutional variables used for calculation of sub-indicators and overall flexibility. For Portugal the resulting value for employment protection was below 0 ( -0.88 e.g. more than two standard deviation below the mean) and therefore was truncated to 0 , which resulted in a slight shift of the mean (4.03) and standard deviation (1.92). In the case of the obtained institutional variable for the educational system in 2003 we are still left with one negative value $(-0.358)$ for Portugal. That means in Portugal the indicator for the educational system is more than two standard deviations below the average of all countries considered. For better interpretation reasons and also because this negative value is close to zero, we truncated this variable to zero resulting in a minor shift of the mean (6.01) and standard deviation (2.97). For Sweden the resulting value for wage flexibility was truncated to zero because the original value was -5 (more than two standard deviations below the mean). This resulted in a minor shift of the mean $(12,1)$ and standard deviation $(5,7)$.

At the third stage all sub-indicators: external numerical, external functional, wage, internal numerical and internal functional flexibility were computed by taking the sum of all corresponding institutional variables. The prior transformation of these institutional variables result in an average of 12 for each sub-indicator and a theoretically standard deviation of 6 , but the standard deviation is subject to the correlation of the institutional variables used. For example: although the standard deviations of the used institutional variables for ALMP and educational system were transformed to 3 the resulting standard deviation for external functional flexibility is 4.68 . If both institutional variables would be negatively correlated (from substitutes to complementary) the resulting standard deviation would be lower than 3, if positively correlated (from substitutes to additives) the standard deviation would be higher than 3 . 
Table A1: Description of sub-indicators of external and wage flexibility

\begin{tabular}{|c|c|c|c|c|}
\hline & Mean & Stddev & Min & Max \\
\hline taxation & 4,0 & 2,0 & 0,1 & 8,9 \\
\hline benefitsystem & 4,0 & 2,0 & 0,7 & 7,5 \\
\hline employmentprotection & 4,0 & 1,9 & 0,0 & 8,6 \\
\hline externalnumericalflexibility & 120 & 44 & 52 & 207 \\
\hline & & & & \\
\hline educationsystem & 6,0 & 3,0 & 0,0 & 11,0 \\
\hline almp & 6,0 & 3,0 & 2,6 & 15,3 \\
\hline externalfunctionalflexibility & 120 & 4.7 & 3.6 & 236 \\
\hline & & & & \\
\hline externalflexibility & 24,0 & 6,0 & 13,6 & 34,8 \\
\hline wage flexibility & 12,1 & 5,7 & 0,0 & 22,6 \\
\hline $\mathrm{N}=25$ & & & & \\
\hline
\end{tabular}

Table A2: Description of sub-indicators of external, internal and wage flexibility

\begin{tabular}{|c|c|c|c|c|}
\hline & Mean & Stddev & Min & Max \\
\hline internalnumericalflexibility & 12,0 & 6,0 & 2,5 & 24,6 \\
\hline internalfunctionalflexibility & 12,0 & 6,0 & 2,9 & 21,8 \\
\hline internalflexibility & 24,0 & 10,2 & 6,3 & 39,3 \\
\hline & & & & \\
\hline taxation & 3,0 & 1,5 & 0,1 & 6,0 \\
\hline benefitsystem & 3,7 & 2,1 & 0,7 & 7,0 \\
\hline employmentprotection & 3,5 & 1,7 & 0,0 & 6,9 \\
\hline externalnumericalflexibility & 102 & 36 & 52 & 174 \\
\hline & & & & \\
\hline educationsystem & 5,0 & 2,6 & 0,0 & 8,9 \\
\hline almp & $\overline{6,8}$ & $\overline{3,2}$ & 3,1 & 15,3 \\
\hline externalfunctionalflexibility & 117 & 52 & 36 & 236 \\
\hline & & & & \\
\hline externalflexibility & 21,9 & 5,2 & 13,6 & 34,7 \\
\hline & & & & \\
\hline wage flexibility & 10,4 & 5,5 & 0,0 & 20,1 \\
\hline OVERALL FLEXIBILITY & 56,4 & 12,9 & 28,3 & 80,6 \\
\hline $\mathrm{N}=16$ & & & & \\
\hline
\end{tabular}




\section{ANNEX 2}
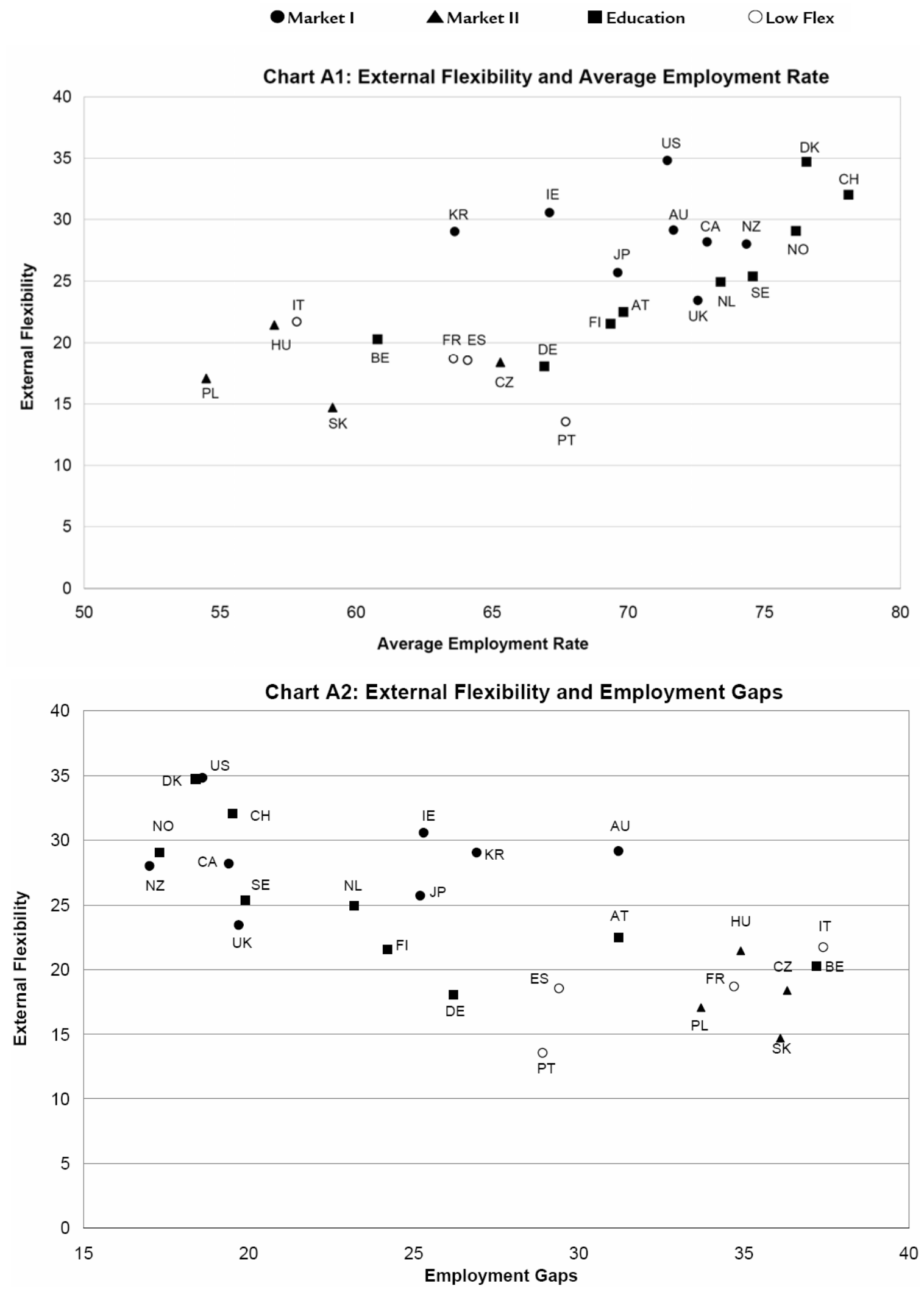


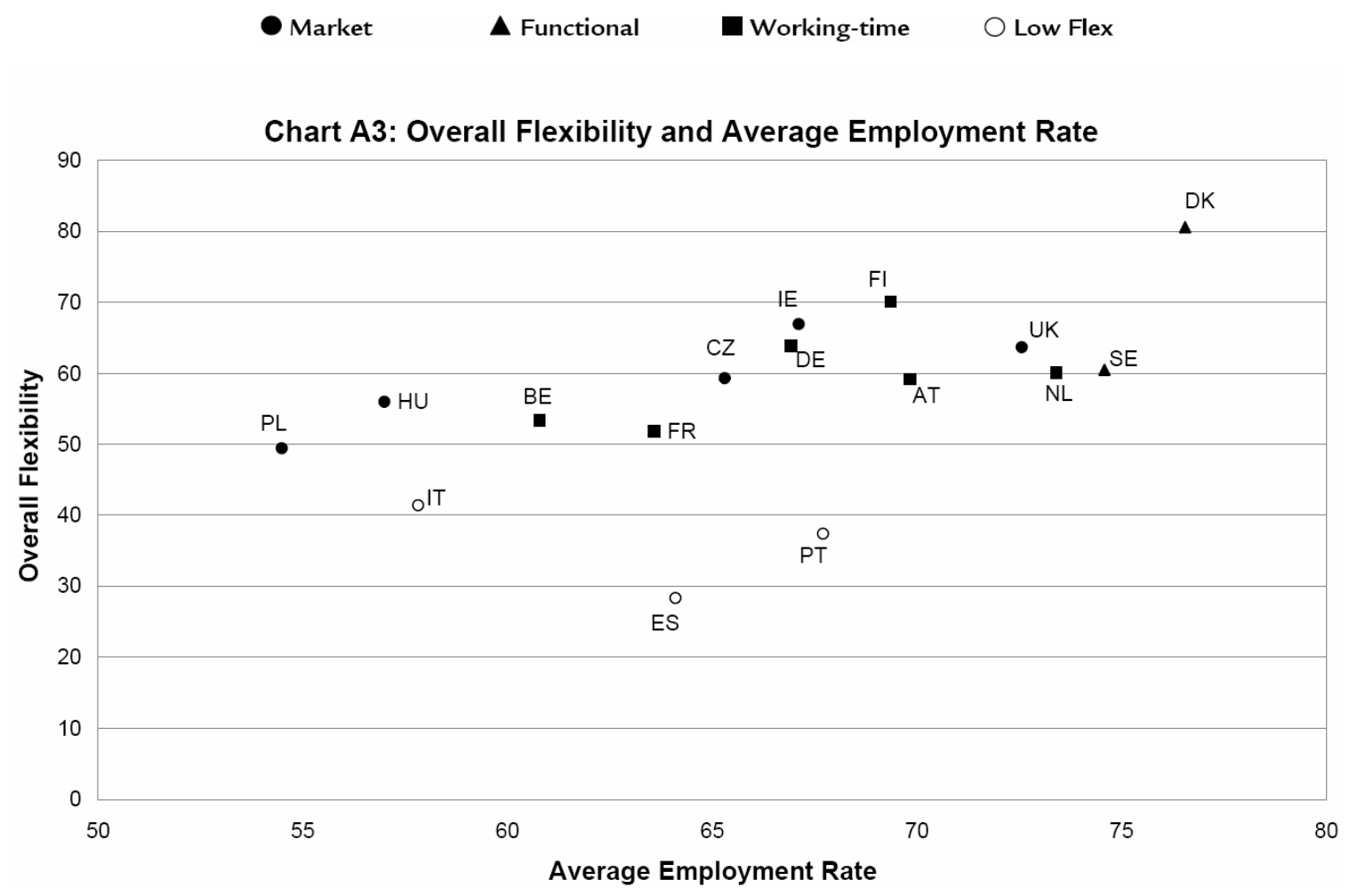


ANNEX 3: Output Variables (External + Wage Flexibility)

\begin{tabular}{|c|c|c|c|c|c|c|c|c|c|c|c|c|c|c|}
\hline \multirow{3}{*}{ Country } & \multicolumn{8}{|c|}{ Quality of Work } & \multicolumn{5}{|c|}{ Performance } & \multirow[b]{3}{*}{ JQI } \\
\hline & \multirow{2}{*}{$\begin{array}{c}\text { Poverty } \\
\text { Rates } \\
(\%)\end{array}$} & \multirow[b]{2}{*}{ Gini } & \multicolumn{2}{|c|}{ Job Tenure } & \multicolumn{3}{|c|}{ Average Gaps } & \multirow{2}{*}{\begin{tabular}{|c|} 
Non-empl. \\
Rate Gap \\
by Educ. \\
$(\%)$
\end{tabular}} & \multicolumn{3}{|c|}{ Average 2003-2008 (15-64 yrs) } & \multirow{2}{*}{$\begin{array}{c}\text { Empl. } \\
\text { Growth } \\
(\% 03-07)\end{array}$} & \multirow[b]{2}{*}{\begin{tabular}{|c|} 
LF Growth \\
$(\% 03-07)$
\end{tabular}} & \\
\hline & & & Average & $\begin{array}{c}\text { Ratio } \\
\text { 1yr / 10yr }\end{array}$ & $\begin{array}{l}\text { Empl/Pop } \\
\text { Ratio (\%) }\end{array}$ & $\begin{array}{l}\text { Particip. } \\
\text { Rate (\%) }\end{array}$ & $\begin{array}{l}\text { Unempl. } \\
\text { Rate (\%) }\end{array}$ & & $\begin{array}{c}\text { Empl. } \\
\text { Rate (\%) }\end{array}$ & $\begin{array}{c}\text { Inactivity } \\
\text { (\%) }\end{array}$ & $\begin{array}{c}\text { Unempl. } \\
\text { Rate (\%) }\end{array}$ & & & \\
\hline United States & 23,9 & 0,37 & & & 18,6 & 18,2 & 2,1 & 27,4 & 71,4 & 24,5 & 5,3 & 1,4 & 1,1 & \\
\hline Ireland & 23,3 & 0,32 & 8,8 & 0,64 & 25,3 & 25,8 & 1,0 & 23,6 & 67,1 & 29,6 & 4,6 & 3,5 & 3,5 & 0,65 \\
\hline Australia & 20,3 & 0,31 & .. & .. & 31,2 & 17,4 & 2,2 & 19,1 & 71,7 & 24,5 & 5,0 & 2,5 & 2,1 & .. \\
\hline Japan & 20,8 & 0,31 & .. & .. & 25,2 & 25,7 & 1,4 & .. & 69,6 & 27,0 & 4,6 & 0,3 & $-0,1$ & .. \\
\hline Korea & 20,8 & 0,30 & .. & .. & 26,9 & 27,4 & 1,8 & 13,7 & 63,6 & 34,0 & 3,6 & 1,1 & 1,1 & .. \\
\hline Canada & 19,0 & 0,32 & .. & .. & 19,4 & 19,4 & 1,9 & 23,9 & 72,9 & 21,8 & 6,7 & 1,9 & 1,6 & .. \\
\hline United Kingdom & 15,5 & 0,34 & 8,6 & 0,60 & 19,7 & 18,8 & 2,4 & 27,4 & 72,6 & 23,6 & 5,1 & 0,9 & 0,9 & 0,70 \\
\hline New Zealand & 22,7 & 0,33 & .. & .. & 17,0 & 16,1 & 2,2 & 17,1 & 74,3 & 22,5 & 4,0 & 2,5 & 2,1 & .. \\
\hline Market-oriented I & 20,8 & 0,33 & 8,7 & 0,62 & 22,9 & 21,1 & 1,9 & 21,7 & 70,4 & 26,0 & 4,9 & 1,8 & 1,6 & 0,67 \\
\hline Denmark & 12,3 & 0,23 & 8,8 & 0,69 & 18,4 & 17,9 & 1,9 & 20,0 & 76,5 & 19,9 & 4,4 & 0,6 & 0,5 & 0,79 \\
\hline Switzerland & 15,2 & 0,27 & 9,6 & 0,42 & 19,5 & 18,9 & 2,0 & 35,1 & 78,1 & 18,6 & 4,1 & 1,0 & 1,1 & .. \\
\hline Norway & 12,4 & 0,28 & 9,9 & 0,43 & 17,3 & 17,0 & 1,8 & 23,0 & 76,2 & 20,9 & 3,7 & 1,4 & 1,1 & .. \\
\hline Sweden & 11,4 & 0,24 & 10,9 & 0,45 & 19,9 & 18,7 & 4,6 & 26,1 & 74,6 & 20,1 & 6,6 & 1,0 & 1,1 & 0,70 \\
\hline Netherlands & 14,4 & 0,27 & 11,2 & 0,19 & 23,2 & 23,0 & 1,8 & 19,1 & 73,4 & 23,4 & 4,1 & 0,5 & 0,5 & 0,74 \\
\hline Austria & 13,4 & 0,27 & 10,6 & 0,35 & 31,2 & 31,5 & 1,9 & 26,2 & 69,8 & 26,8 & 4,6 & 0,6 & 0,6 & 0,62 \\
\hline Finland & 14,8 & 0,27 & 10,7 & 0,51 & 24,2 & 23,7 & 4,2 & 26,3 & 69,4 & 24,7 & 7,9 & 1,0 & 0,5 & 0,69 \\
\hline Belgium & 16,2 & 0,27 & 12,3 & 0,25 & 37,2 & 38,6 & 3,8 & 25,1 & 60,8 & 34,2 & 7,6 & 0,9 & 0,9 & 0,67 \\
\hline Germany & 17,2 & 0,30 & 10,9 & 0,32 & 26,2 & 28,0 & 2,2 & 27,0 & 66,9 & 26,0 & 9,6 & 0,3 & 0,1 & 0,50 \\
\hline Education-based & 14,1 & 0,27 & 10,5 & 0,40 & 24,1 & 24,1 & 2,7 & 25,3 & 71,7 & 23,9 & 5,8 & 0,8 & 0,7 & 0,67 \\
\hline Czech Republic & 11,5 & 0,27 & 9,9 & 0,28 & 36,3 & 37,2 & 4,5 & 50,1 & 65,3 & 29,9 & 6,9 & 0,7 & 0,3 & 0,42 \\
\hline Slovak Republic & 13,7 & 0,27 & 10,1 & 0,23 & 36,1 & 39,7 & 5,4 & 53,1 & 59,1 & 31,0 & 14,3 & 2,1 & 0,3 & 0,39 \\
\hline Poland & 20,8 & 0,38 & 11,2 & 0,31 & 33,7 & 37,3 & 6,5 & 33,8 & 54,5 & 36,1 & 14,7 & 2,1 & $-0,4$ & 0,29 \\
\hline Hungary & 12,3 & 0,30 & 9,6 & 0,32 & 34,9 & 36,3 & 3,7 & 36,9 & 57,0 & 38,7 & 7,0 & 0,3 & 0,7 & 0,39 \\
\hline Market-oriented II & 14,6 & 0,31 & 10,2 & 0,29 & 35,3 & 37,6 & 5,0 & 43,5 & 59,0 & 33,9 & 10,7 & 1,3 & 0,2 & 0,37 \\
\hline France & 14,1 & 0,28 & 12,0 & 0,30 & 34,7 & 36,0 & 3,9 & 20,7 & 63,6 & 30,6 & 8,4 & 0,6 & 0,5 & 0,57 \\
\hline Spain & 21,0 & 0,31 & 9,6 & 0,63 & 29,4 & 28,9 & 5,0 & 10,2 & 64,1 & 28,8 & 10,0 & 3,7 & 3,1 & 0,39 \\
\hline Portugal & 20,7 & 0,38 & 11,8 & 0,26 & 28,9 & 29,5 & 3,3 & $-2,6$ & 67,7 & 26,6 & 7,8 & 0,1 & 0,8 & 0,41 \\
\hline Italy & 19,7 & 0,35 & 11,8 & 0,25 & 37,4 & 37,6 & 6,0 & 20,7 & 57,8 & 37,5 & 7,4 & 1,2 & 0,6 & 0,46 \\
\hline Low Flexibility & 18,9 & 0,33 & 11,3 & 0,36 & 32,6 & 33,0 & 4,6 & 12,3 & 63,3 & 30,9 & 8,4 & 1,4 & 1,2 & 0,46 \\
\hline
\end{tabular}


ANNEX 4: Output Variables (Overall Flexibility)

\begin{tabular}{|c|c|c|c|c|c|c|c|c|c|c|c|c|c|c|}
\hline \multirow{3}{*}{ Country } & \multicolumn{8}{|c|}{ Quality of Work } & \multicolumn{5}{|c|}{ Performance } & \multirow[b]{3}{*}{ JQI } \\
\hline & \multirow{2}{*}{$\begin{array}{l}\text { Poverty } \\
\text { Rates } \\
(\%)\end{array}$} & \multirow[b]{2}{*}{ Gini } & \multicolumn{2}{|c|}{ Job Tenure } & \multicolumn{3}{|c|}{ Average Gaps } & \multirow{2}{*}{$\begin{array}{c}\text { Non-empl. } \\
\text { Rate Gap } \\
\text { by Educ. } \\
(\%)\end{array}$} & \multicolumn{3}{|c|}{ Average 2003-2008 (15-64 yrs) } & \multirow{2}{*}{$\begin{array}{c}\text { Empl. } \\
\text { Growth } \\
(\% 03-07)\end{array}$} & \multirow[b]{2}{*}{$\begin{array}{c}\text { LF Growth } \\
(\% 03-07)\end{array}$} & \\
\hline & & & Average & $\begin{array}{c}\text { Ratio } \\
\text { 1yr / 10yr }\end{array}$ & $\begin{array}{l}\text { Empl/Pop } \\
\text { Ratio (\%) }\end{array}$ & $\begin{array}{l}\text { Particip. } \\
\text { Rate (\%) }\end{array}$ & $\begin{array}{l}\text { Unempl. } \\
\text { Rate (\%) }\end{array}$ & & $\begin{array}{c}\text { Empl. } \\
\text { Rate (\%) }\end{array}$ & $\begin{array}{c}\text { Inactivity } \\
\text { (\%) }\end{array}$ & $\begin{array}{l}\text { Unempl. } \\
\text { Rate (\%) }\end{array}$ & & & \\
\hline Ireland & 23.3 & 0.32 & 8.8 & 0.64 & 25.3 & 25.8 & 1.0 & 23.6 & 67.1 & 29.6 & 4.6 & 3.5 & 3.5 & 0.65 \\
\hline United Kingdom & 15.5 & 0.34 & 8.6 & 0.60 & 19.7 & 18.8 & 2.4 & 27.4 & 72.6 & 23.6 & 5.1 & 0.9 & 0.9 & 0.70 \\
\hline Hungary & 12.3 & 0.30 & 9.6 & 0.32 & 34.9 & 36.3 & 3.7 & 36.9 & 57.0 & 38.7 & 7.0 & 0.3 & 0.7 & 0.39 \\
\hline Poland & 20.8 & 0.38 & 11.2 & 0.31 & 33.7 & 37.3 & 6.5 & 33.8 & 54.5 & 36.1 & 14.7 & 2.1 & -0.4 & 0.29 \\
\hline Czech Republic & 11.5 & 0.27 & 9.9 & 0.28 & 36.3 & 37.2 & 4.5 & 50.1 & 65.3 & 29.9 & 6.9 & 0.7 & 0.3 & 0.42 \\
\hline Market-oriented & 16.7 & 0.32 & 9.6 & 0.4 & 30.0 & 31.1 & 3.6 & 34.4 & 63.3 & 31.6 & 7.6 & 1.5 & 1.0 & 0.49 \\
\hline Denmark & 12.3 & 0.23 & 8.8 & 0.69 & 18.4 & 17.9 & 1.9 & 20.0 & 76.5 & 19.9 & 4.4 & 0.6 & 0.5 & 0.79 \\
\hline Sweden & 11.4 & 0.24 & 10.9 & 0.45 & 19.9 & 18.7 & 4.6 & 26.1 & 74.6 & 20.1 & 6.6 & 1.0 & 1.1 & 0.70 \\
\hline Functional & 11.9 & 0.24 & 9.9 & 0.6 & 19.2 & 18.3 & 3.3 & 23.1 & 75.6 & 20.0 & 5.5 & 0.8 & 0.8 & 0.75 \\
\hline Netherlands & 14.4 & 0.27 & 11.2 & 0.19 & 23.2 & 23.0 & 1.8 & 19.1 & 73.4 & 23.4 & 4.1 & 0.5 & 0.5 & 0.74 \\
\hline Austria & 13.4 & 0.27 & 10.6 & 0.35 & 31.2 & 31.5 & 1.9 & 26.2 & 69.8 & 26.8 & 4.6 & 0.6 & 0.6 & 0.62 \\
\hline Finland & 14.8 & 0.27 & 10.7 & 0.51 & 24.2 & 23.7 & 4.2 & 26.3 & 69.4 & 24.7 & 7.9 & 1.0 & 0.5 & 0.69 \\
\hline Belgium & 16.2 & 0.27 & 12.3 & 0.25 & 37.2 & 38.6 & 3.8 & 25.1 & 60.8 & 34.2 & 7.6 & 0.9 & 0.9 & 0.67 \\
\hline France & 14.1 & 0.28 & 12.0 & 0.30 & 34.7 & 36.0 & 3.9 & 20.7 & 63.6 & 30.6 & 8.4 & 0.6 & 0.5 & 0.57 \\
\hline Germany & 17.2 & 0.30 & 10.9 & 0.32 & 26.2 & 28.0 & 2.2 & 27.0 & 66.9 & 26.0 & 9.6 & 0.3 & 0.1 & 0.50 \\
\hline Working Time & 15.0 & 0.28 & 11.3 & 0.3 & 29.5 & 30.1 & 3.0 & 24.1 & 67.3 & 27.6 & 7.0 & 0.7 & 0.5 & 0.63 \\
\hline Spain & 21.0 & 0.31 & 9.6 & 0.63 & 29.4 & 28.9 & 5.0 & 10.2 & 64.1 & 28.8 & 10.0 & 3.7 & 3.1 & 0.39 \\
\hline Portugal & 20.7 & 0.38 & 11.8 & 0.26 & 28.9 & 29.5 & 3.3 & -2.6 & 67.7 & 26.6 & 7.8 & 0.1 & 0.8 & 0.41 \\
\hline Italy & 19.7 & 0.35 & 11.8 & 0.25 & 37.4 & 37.6 & 6.0 & 20.7 & 57.8 & 37.5 & 7.4 & 1.2 & 0.6 & 0.46 \\
\hline Low Flexibility & 20.5 & 0.35 & 11.1 & 0.4 & 31.9 & 32.0 & 4.8 & 9.4 & 63.2 & 31.0 & 8.4 & 1.7 & 1.5 & 0.42 \\
\hline
\end{tabular}

